FEDERAL RESERVE BANK OF SAN FRANCISCO

WORKING PAPER SERIES

\title{
Measuring the Natural Rate of Interest Redux
}

\author{
Thomas Laubach \\ Board of Governors of the Federal Reserve System \\ John C. Williams \\ Federal Reserve Bank of San Francisco
}

October 2015

Working Paper 2015-16

http://www.frbsf.org/economic-research/publications/working-papers/wp2015-16.pdf

\section{Suggested citation:}

Laubach, Thomas, John C. Williams. 2015. "Measuring the Natural Rate of Interest Redux." Federal Reserve Bank of San Francisco Working Paper 2015-16.

http://www.frbsf.org/economic-research/publications/working-papers/wp2015-16.pdf

The views in this paper are solely the responsibility of the authors and should not be interpreted as reflecting the views of the Federal Reserve Bank of San Francisco or the Board of Governors of the Federal Reserve System. 


\title{
Measuring the Natural Rate of Interest Redux*
}

\author{
Thomas Laubach \\ Board of Governors of the Federal Reserve System \\ and \\ John C. Williams \\ Federal Reserve Bank of San Francisco
}

October 31, 2015

\begin{abstract}
Persistently low real interest rates have prompted the question whether low interest rates are here to stay. This essay assesses the empirical evidence regarding the natural rate of interest in the United States using the Laubach-Williams model. Since the start of the Great Recession, the estimated natural rate of interest fell sharply and shows no sign of recovering. These results are robust to alternative model specifications. If the natural rate remains low, future episodes of hitting the zero lower bound are likely to be frequent and long-lasting. In addition, uncertainty about the natural rate argues for policy approaches that are more robust to mismeasurement of natural rates.
\end{abstract}

\footnotetext{
* The views expressed here are solely those of the authors and do not necessarily reflect those of others in the Federal Reserve System. We thank Ben Pyle for excellent research assistance. Contact information: Laubach: Board of Governors of the Federal Reserve System, Washington, DC 20551; email: thomas.laubach@frb.gov; Williams: Federal Reserve Bank of San Francisco, 101 Market St., San Francisco, CA 94105; email: john.c.williams@ @ff.frb.org; phone: 415-9742121.
} 
Year after year of extraordinarily low interest rates in the United States and elsewhere have prompted the question whether low interest rates are a permanent feature of the future economic landscape. The answer to this question has important implications for the economy, asset prices, and monetary policy. A great deal has been written on why the equilibrium or "natural" real interest rate may be low in the future, with the theory of secular stagnation one prominent example (Summers 2014). In this essay, we assess the empirical evidence regarding the historical behavior of the natural rate of interest in the United States, with a particular focus on the period since the outbreak of the global financial crisis. We then turn to implications for monetary policy.

Our analysis centers on the model that we developed to measure highly persistent movements in the natural rate of interest (Laubach and Williams 2003). According to this model, since the start of the Great Recession the natural rate of interest has fallen to, and remained at, historically very low levels near zero. This is in part explained by a significant decline in the trend growth rate of the economy, but other factors that are harder to pin down are also at play. We find no evidence that the natural rate has moved back up even with the economy close to fully recovered from the Great Recession. These results are robust to alternative approaches to estimating the natural rate of interest and the output gap.

In the final part of this essay we consider two key policy implications of a variable natural rate of interest in general, and of the decline and subsequent low level of the natural rate since the Great Recession in particular. First, uncertainty about the natural rate of interest argues in favor of policy approaches that deemphasize the role of the natural rate in policy decisions and therefore make these decisions more robust to potentially mismeasured natural rates. Second, if the natural rate were to remain as low as it has been since 2008, episodes in which short-term 
interest rates would be constrained from below would become more frequent and long-lasting, and unconventional policy tools may continue to play an important role in the future.

\section{Defining the natural rate of interest}

Knut Wicksell (1898) famously characterized the natural rate of interest: "There is a certain rate of interest on loans which is neutral in respect to commodity prices, and tends neither to raise nor to lower them." We operationalize this notion by defining the natural rate as the real short-term interest rate consistent with the economy operating at its full potential once transitory shocks to aggregate supply or demand have abated. Implicit in this definition is the absence of upward or downward pressures on the rate of price inflation relative to its trend. Our definition takes a "longer-run" perspective, in that it refers to the level of real interest rates expected to prevail, say, five to 10 years in the future, after the economy has emerged from any cyclical fluctuations and is expanding at its trend rate.

In contrast, other research has focused on short-term fluctuations in the natural rate of interest, assuming the longer-run value is constant (Neiss and Nelson 2003, Woodford 2003, Andres et al., 2009, Barsky et al., 2014, Curdia et al., 2015, Goldby et al., 2015). These studies define the natural rate to be the real interest rate that would prevail if all prices were flexible. However, we do not view this as a competing or contradictory approach to defining the natural rate; rather, the short-term perspective is complementary to our longer-run approach.

Figure 1 portrays a highly stylized model of the determination of the natural rate. The downward-sloping line, labelled the IS curve, shows the negative relationship between aggregate spending and the real interest rate. The vertical line indicates the level of potential GDP, which is assumed to be unrelated to the real interest rate for this diagram. In principle, potential GDP may 
also a function of the real rate, but this modification does not affect the basic point of the analysis. At the intersection of the IS curve and the potential GDP line, real GDP equals potential, and the real interest rate equals the natural rate of interest.

The natural rate of interest may change over time owing to highly persistent structural shifts in aggregate supply and demand. For example, Laubach (2009) finds that increases in long-run projections of federal government budget deficits are related to increases in expected long-term real interest rates. In Figure 1, an increase in long-run projected budget deficits moves the IS curve to the right, implying a higher natural rate. As discussed by Bomfim (1997), Laubach and Williams (2003), Congressional Budget Office (2014), International Monetary Fund (2014), Council of Economic Advisers, 2015, Hamilton et al. (2015), and Pescatori and Turunen (2015), there are myriad influences on the natural rate, including, but not limited to, productivity growth, demographics, and the evolution of the global economy.

\section{Univariate time series estimates}

Although it is relatively straightforward to define the natural rate of interest, it is more challenging to pin it down quantitatively. If the natural rate were close to constant over time and there were no trend in the inflation rate, a reasonable estimate would be the sample mean of actual real interest rates. For example, the ex post real fed funds rate--defined as the nominal effective federal funds rate less the percent change in the personal consumption expenditures price index over the prior year-- has averaged about $2 \%$ over the past 50 years. If history were a good guide, then one would expect real interest rates to return to $2 \%$ in the future. However, factors affecting supply and demand evolve over time, shifting the natural rate around. If these 
movements are sufficiently large and persistent, the long-term average is a poor predictor of the natural rate of interest.

A standard way to allow for persistent changes is to compute multi-year averages of past values. Figure 2 illustrates this approach, showing the ten-year moving average of ex post real short-term interest rates in the United States and the corresponding figure for the median real short-term interest rate across 17 advanced economies. The data are from an updated version of the Schularick and Taylor (2012) data set. One observation stands out from this figure: there are sizable swings in average real interest rates that persist for decades.

Other more sophisticated statistical approaches use time-series filtering techniques that try to separate longer-term trends from short-term variations. Figure 3 shows three such sets of estimates of the medium- or longer-term trends using the Hodrick-Prescott filter, the bandpass filter, and an unobserved components stochastic volatility model (Stock and Watson 2007). The five-year moving average of real interest rates is also shown for comparison.

Although such univariate time series methods could in principle work well at estimating the natural rate of interest when inflation and economic activity are relatively stable, they are likely to be unreliable during periods when this is not the case, indicating that real interest rates have deviated from the natural rate for some time. For example, during the late 1960s and much of the 1970s, inflation trended steeply upward in the United States, which suggests that the real funds rate was below the natural rate on average. Similarly, real interest rates were very high during the period of the Volcker disinflation of the early 1980s, when inflation fell sharply. The univariate time series approaches cannot control for these developments and ascribe this pattern of low, and then high, real interest rates to the trend in real interest rates, as seen in the figure. 
In addition, univariate methods such as these mechanically ascribe the persistently low real interest rates during and after the Great Recession to the trend. This is seen by the convergence of all trend estimates shown in Figure 3 to about -1.5 percent at the end of the sample. Hamilton et al. (2015) come to a similar conclusion using international data.

An alternative approach that could overcome some of these problems is to use forward rates taken from yields on longer-term Treasury securities to measure market participants' perceptions of the natural rate. In principle, forward rates should measure interest rates expected to prevail in the future, rather than simply be a reflection of current interest rates. Figure 4 shows estimates of the trend in seven-year ahead real short-term interest rates for the United States. These are constructed by applying statistical filters to the difference between the seven-year-ahead zerocoupon one-year yield and core inflation rate over the past year. These measures are not nearly as volatile as those shown in Figure 3. Nonetheless, they show sizable movements up and down over time, with relatively low readings at the end of the sample.

However, this approach is also problematic as a measure of the natural rate. Forward rates include a term premium that contaminates the measurement of the market perception of the natural short-term interest rate. For example, Kim and Wright (2005) find that movements in the term premium are a major source of variation in far-ahead forward rates. This implies that forward rates are not a reliable measure of expectations of future interest rates.

\section{Multivariate Kalman filter estimates: the Laubach-Williams model}

In light of these problems in applying univariate time series methods to estimate the natural rate of interest, we instead use a multivariate model that explicitly takes into account movements in inflation, output, and interest rates. In the Laubach-Williams (2003) model, the natural rate of 
interest is implicitly defined by the absence of inflationary or deflationary pressures. It implements the principle, poetically stated by John H. Williams (1931) that: "The natural rate is an abstraction; like faith, it is seen by its works. One can only say that if the bank policy succeeds in stabilizing prices, the bank rate must have been brought in line with the natural rate, but if it does not, it must not have been."

In the Laubach-Williams (LW) model, the natural rate of interest is assumed to change over time due to various influences. In principle, one would like to use data on the factors that influence the natural rate in order to quantify the effects. In practice, these are difficult to measure using available data and methods. In light of these data limitations, in the empirical implementation of the LW model, a parsimonious specification for the determinants of the natural rate is used. Specifically, the natural rate is assumed to depend on the estimated contemporaneous trend growth rate of potential output and a time-varying unobserved component that captures the effects of other unspecified influences on the natural rate. In mathematical terms, the natural rate of interest, denoted $\mathbf{r}^{*}$, is given by:

(1) $r_{t}^{*}=c g_{t}^{*}+z_{t}$,

where $\mathbf{g}^{*}$ is the estimated trend growth rate of potential GDP, $\mathbf{z}$ is an unobserved component that is assumed to follow a random walk process, and $\mathbf{c}$ is an estimated coefficient that measures the influence of the trend growth rate on the natural rate of interest. In a recent note, Dupor (2015) proposes a simpler model of the natural rate which excludes the $\mathbf{z}$ term. Based on statistical tests, the data reject such a restriction and support inclusion of the additional unobserved factor (see Laubach and Williams, 2003, for a more complete discussion). 
The model is estimated using the Kalman filter. In words, the Kalman filter works on the principle that one should partially adjust one's estimate of the unobserved variables - the natural rate of interest, the level of potential output, and its trend growth rate - based on the distance between the model's predictions for real GDP and inflation and the actual outcomes. Roughly speaking, for a given estimate of the output gap (or equivalently potential output), the model uses an estimated IS curve relating the output gap to its own lags and the lagged "real rate gap" - the difference between the actual real interest rate and the natural rate - to form a prediction for the output gap next period. If the output gap turns out to be lower than expected, the model responds by reducing the estimate of the natural rate by a small fraction.

The output gap estimate in turn is informed by an estimated Phillips curve that relates core inflation to its own lags, the lagged output gap, and movements in the relative prices of oil and non-energy imports. In particular, if inflation turns out lower than predicted by the existing estimates for potential output, the level of potential output is being revised up (that is, for a given level of real GDP, the output gap is revised down), with most of this revision assigned to an innovation that affects only the level of potential GDP, and only a relatively small fraction assigned to the trend growth rate.

\section{Estimation Results}

The LW estimates of the natural rate of interest display two periods of significant declines: a moderate secular decline over the two decades preceding the Great Recession, and a second, more substantial decline during the Great Recession (Williams 2015). Figure 5 shows the LW estimates of the natural rate of interest from 1980 through the first half of 2015. These are the so-called one-sided estimates, where the model parameters are estimated using the entire 
data sample, but the estimates of the natural rate are based on the past history of the data on GDP, interest rates, and other model variables only through the date indicated. As can be seen in the figure, the estimate of the natural rate was about 3-1/2 percent for 1990. It fluctuates over time but exhibits a downward trend, reaching about 2 percent in 2007, on the cusp of the Great Recession.

How did the Kalman filter respond to the economic experience of the Great Recession? With core inflation remaining surprisingly stable in the face of sharp declines of real GDP below the trend implied by the pre-crisis trend growth rate of around 3 percent, the model assigned some of the unexpected output declines to the output gap, but also a large share to declines in potential output and its trend growth rate. In fact, from mid-2008 to mid-2009, the model saw the level of potential output contracting by $2 \frac{1 / 4}{4}$ percent, and the estimate of the trend growth rate declined by nearly $1 / 2$ percentage point. The slow pace of GDP growth over the subsequent three years, combined with stable inflation, reduced the trend growth estimate further, to roughly $2 \frac{1 / 4}{4}$ percent. While the output gap began to narrow gradually beginning in mid-2009, the model's other key relationship, the IS curve, would have predicted a much faster return of the output gap to zero if the estimate of $r^{*}$ had remained at its pre-recession value near 2 percent. With the federal funds rate close to zero from early 2009 on, and core inflation averaging around 1-1/2 percent, the implied real rate gap would have been $-3-1 / 2$ percent. Such a large negative real rate gap would have predicted a much sharper rebound in the output gap than actually occurred. The (one-sided) estimate of $\mathrm{r}^{*}$ therefore fell rapidly to $1 / 2$ percent in mid-2009, and then continued to decline to around zero by the end of 2010 , cutting the implied real rate gap to about $-1-1 / 2$ percent.

This represents an unprecedented decline and an historical low level of the natural rate over the past half century for which we have estimates. The persistently low level of the natural 
rate during the past few years owes to the fact that GDP continues to grow only slightly above the estimated trend growth rate, despite the real federal funds rate remaining well below zero and the estimated trend growth rate itself having declined by nearly a percentage point. The Kalman filter interprets this combination of moderate growth and negative real interest rates as indicating a very low level of the natural rate of interest. Even with the economy mostly recovered from the recession, there is no sign of a rebound in the natural rate of interest.

This pattern of declining natural rates of interest is also seen in estimates implied by economic forecasts and yields on Treasury inflation-protected securities (TIPS), reported in Table 1. The first row of the table reports natural rate estimates implied by the long-run forecasts from the Blue Chip survey of forecasters. The second row reports real interest rates five to 10 years in the future based on TIPS yields. Note that TIPS did not exist in 1990. The third row of the table reports the LW estimates. The LW model uses the personal consumption price index for the measure of inflation adjustment, while the Blue Chip and TIPS-based measures use the consumer price index, so these are not directly comparable in the levels. However, this does not materially affect comparisons of the different measures' changes over time, shown in the final two columns of the table. Interestingly, the pattern of decline in natural rates is consistent across the three measures, although the movements in the LW estimates are much larger than the other two measures.

While it is not possible to ascertain the reasoning behind the changes in the Blue Chip and TIPS-based measures, the LW model ascribes the slowdown in potential GDP growth a major role in the decline in the natural rate over the past 25 years. The final two rows of Table 1 report the contributions from changes in trend growth and the catch-all "other factors" to the decline in the estimated natural rate for the two periods, 1990-2007 and 2007-2015 (our sample 
ends in the second quarter of 2015, so for the final year we take the average over the first half of 2015). The estimated value of the coefficient $\mathbf{c}$ is 1.3 , indicating that a one percentage point decline in the trend growth rate lowers the estimate of the natural rate of interest by 1.3 percentage points.

Overall, the decline in trend growth accounts for nearly one half of the decline in the natural rate and a little over one-half is accounted for by other unspecified factors. For reference, Figure 6 shows the LW model estimates of the trend growth rate of potential output over 19802015. Estimated trend potential output growth was about 3-1/2 percent in 1990, declining to 3 percent in 2007, then falling sharply to a little above 2 percent. Note that the model cannot attribute these movements in trend potential output growth to specific sources, instead these are the values generated by the model estimation procedure that maximizes the fit to the data.

One criticism of the LW natural rate estimates are that they can be subject to sizable revisions as additional and revised data become available (Clark and Kozicki 2005). Although this can be an issue with any model estimates, it is striking that in the recent episode, the LW estimates of the natural rate have been remarkably consistent. Figure 5 compares the ex post one-sided LW estimates of the natural rate to the corresponding real-time estimates over 20072015. The real-time estimates represent the estimate of the natural rate based solely on data available a few months after the end of the quarter for which the estimate is reported. By construction, the real-time and ex post estimates are identical for the final data point in our sample (the second quarter of 2015). 


\section{Robustness to alternative specifications}

The standard LW model incorporates a number of assumptions that potentially influence the estimates of the natural rate of interest. In this section, we consider the sensitivity of the LW estimates to alternative assumptions about key macroeconomic relationships. In particular, we consider alternative specifications regarding the processes for output and the natural rate of interest. We also examined alternative specifications for the inflation equation, but these had relatively modest effects on the estimation results and are not reported here.

Replacing GDP with per capita GDP in the model has little effect on the estimates. Economic theory suggests a positive relationship between output growth and the natural rate of interest, but it is not clear whether this should be in terms of overall growth or per capita growth. To assess the relevance of this distinction, we estimated a version of the LW model replacing real GDP with per capita real GDP. The resulting estimates of the natural rate of interest are shown in Figure 6. These are very close to those from the standard LW model, as are the output gap estimates, shown in Figure 7. Evidently, the model specification is flexible enough to handle the differences in these data series.

The LW model jointly estimates the level and growth rate of potential output and explicitly links the trend growth rate for potential output and the natural rate. We now consider a version of the model where these assumptions are relaxed. Specifically, we use an estimate of potential output from a different model, namely that of Fleischman and Roberts (2011; data updated through 2015Q2), and do not impose any relationship between trend growth and the natural rate. The natural rate of interest is instead assumed to follow an exogenous random walk. The alternative model estimates of the output gap are shown in Figure 8. They differ at times 
significantly from the corresponding LW estimates, especially during the recent recession when the LW estimates show a much more muted decline in the output gap.

Despite these major differences in the two models, the resulting estimates of the natural rate are broadly similar. As seen in Figure 7, the alternative natural rate estimates are somewhat more volatile than the LW estimates, but tend to move together over time. The alternative estimates decline from 4.1 percent in 1990 to 2.4 percent in 2007, before plummeting to -1.4 percent in the first half of 2015 .

Lubik and Matthes (2015) estimate a very different model and find estimates of the natural rate of interest that are close to the standard LW estimates for the past 35 years. Their final estimate of the natural rate, based on data through the second quarter of 2015, is 0.5 percent. Overall, all of these results indicate that the main finding that the natural rate has experienced an unprecedented decline since the start of the recession is robust to alternative assumptions regarding the output gap and the relationship between trend growth and the natural rate.

\section{Are movements in the natural rate permanent?}

The LW model assumes that the recent decline in the natural rate is permanent; that is, the natural rate will stay at historic lows for the indefinite future. However, distinguishing between highly persistent and truly permanent movements in economic variables is very difficult. It could be that the unusual decline and long period of the very low natural rate represents unusually long-lasting effects of the recession, but eventually the natural rate will return to a more normal level. In this section, we assess the evidence on this question. 
The first question is whether real interest rates can spend very long periods away from its unconditional mean. Visual inspection of figure 2 makes it clear that this is the case. There are decades-long periods of high and low real interest rates. This conclusion is further supported by the estimates of the LW model from postwar U.S. data, which indicate the presence of permanent movements in the natural rate of interest (see Laubach and Williams 2003 for a more detailed discussion of the statistical evidence). Of course, this evidence does not prove that the recent decline in the natural rate is permanent, but it does dispel arguments that it can't be so.

The second question is whether financial crises invariably lead to long periods of low real interest rates and we are simply experiencing another case of history repeating itself. To examine this hypothesis, we follow the approach of Schularick, and Taylor (2012) and Jordà, Schularick, and Taylor (2012). We measure the effects of financial crises using a dataset of 17 countries over 140 years. Specifically, we compare the level of real short-term interest rates several years after a financial crisis to levels seen in years when there has not been a crisis. Figure 9 shows the results visually. We consider separately the pre- and post-war samples. In neither case can we see any evidence that crises are typically followed by lower than normal real interest rates. Indeed, if anything, real rates tend to be somewhat higher following crises. Table 2 reports formal econometric analysis that distinguishes between different types of recessions and crises. The result is the same: there is no evidence that real interest rates are typically lower five years after a crisis. This negative finding is robust across samples, countries, and time horizons.

So, where does that leave us? One hypothesis is that low real rates are the new normal. The evidence of favor of this conclusion is that the LW model estimates show no signs of rebounding, six years after the end of the recession. Nor is this picture likely to change over the next year or so. If we plug in the median forecast from the Survey of Professional Forecasters 
(SPF) into the LW model and run in through the third quarter of 2016Q3, the estimates of the natural rate of interest barely budge, rising to about zero. The reason for this prediction is that the SPF respondents expect only moderate growth in GDP and a gradual increase in inflation over the next year, while the forecast for the short-term real interest rate remains below zero.

The alternative hypothesis is that the headwinds holding back growth will eventually calm and the natural rate will return to a more normal level. This view is possible, but it has proven an unreliable guide during the past seven years. Models of the natural rate of interest with mean reversion would have repeatedly and erroneously forecast the natural rate to rise. This characteristic is clearly portrayed by the short-run natural rate estimates from a DSGE model reported by Cúrdia (2015) and shown in Figure 10. This model assumes that all shocks are transitory so the natural rate tends to return to its unconditional mean after a few years. Various vintages of model forecasts, starting from 2006 and running through the most recent vintage, are shown in the figure. Each forecast predicts a quick return to a natural rate of about 2 percent, but these forecasts are contradicted by the data and the model estimates of the prevailing natural rate remain very depressed.

To further examine the possibility of a rebound in the natural rate, we estimated a version of the LW model where the unobserved factors influencing the natural rate - the variable $\mathbf{z}$ in the model — are assumed to be mean reverting. We model this as a first-order autoregressive process. We maintain the assumption that the natural rate is affected by the trend growth rate of potential GDP. In this model, the natural rate has a permanent component and a transitory component. Therefore, one can distinguish between a shorter-run notion of the natural rate that includes the transitory component and a long-run notion that includes only the permanent component. The estimated long-run natural rate is given by: $\mathrm{r}_{\mathrm{LR}}^{*}=-3.3+2.0 \mathrm{G}^{*}$. Figure 11 
shows the short-run and long-run estimates of the natural rate for this alternative model. The standard LW estimates are shown for comparison.

These alternative estimates of the natural rate are qualitatively similar to those from the standard LW model. The short-run estimates are naturally more variable, but the pattern of very low natural rates since the most recent recession is consistent with the LW model estimates. The short-run natural rate estimate for the first half of 2015 is -0.1 percent, nearly the same as the LW estimate. The long-run estimates, on the other hand, are less variable than the LW estimates, but nonetheless display the same pattern of decline over the past 25 years as the LW estimates. Specifically, the estimates fall from 3.3 percent in 1990 to 2.6 percent in 2007 , and end up at 0.8 percent in the first half of 2015. By construction, these declines are entirely due to the downward trend in the estimates of trend growth of potential GDP. In fact, the model estimate of the relationship between the natural rate and the trend growth rate is much larger than in the baseline LW model. Evidently, the data strongly support a sizable decline in the natural rate in the latter part of the sample and in the alternative model this is achieved through a larger coefficient on the trend growth rate of potential GDP.

Overall, this evidence suggests that a very low natural rate of interest may well be with us for a long time. Although individual estimates differ, it is striking that a wide variety of approaches point to historically low levels of future real interest rates (Hamilton et al., 2014, Johannsen and Mertens, 2015, Kiley, 2015, Lubik and Matthes, 2015). Market participants have come to share this perspective, as seen in economists' surveys, yields on TIPS, and forward rates, as discussed above. 


\section{Monetary policy}

What are the implications of changes in the natural rate of interest for monetary policy, and especially of the apparent sizeable decline in recent years? First, time variation in the natural rate of interest poses a challenge for the conduct of monetary policy, because it affects the appropriate stance of monetary policy. This point is most easily illustrated in the case in which

there is a permanent decline in the natural rate, say from $r^{*}$ to $r^{* \prime}$. Consider the implications for a policymaker who is setting the policy rate according to the Taylor rule

(2) $i_{t}=\hat{r}^{*}+\pi_{t}+\alpha\left(\pi_{t}-\pi^{*}\right)+\beta Y_{t}$.

Here, $i$ denotes the nominal short-term interest rate, $\hat{r}^{*}$ is the policymaker's current assumed value of the natural rate of interest rate, $\pi$ is the inflation rate, $\pi^{*}$ is the policymaker's inflation objective, and $Y$ is the output gap. Absent any disturbances, the output gap would converge to zero and the real interest rate $i-\pi$ would converge to $r^{* \prime}$. Then the policy rule implies that (3) $r^{* \prime}-\hat{r}^{*}=\alpha\left(\pi-\pi^{*}\right)$.

Accordingly, only if the intercept $\hat{r}^{*}$ in the policy rule (equation 2 ) is equal to the true value $r^{* \prime}$ will the policymaker achieve the inflation objective over time. If, by contrast, the policymaker assumed that the natural rate had remained at its previous, higher level of $r^{*}$, inflation will over time run below the inflation objective by an amount $\left(r^{*}-r^{* \prime}\right) / \alpha$. Intuitively speaking, the intercept $\hat{r}^{*}$ pulls the nominal interest rate toward too high a level, and this effect is only partially offset by the pull in the opposite direction exerted from inflation running below the objective.

This point brings us back to issues of measurement of the natural rate of interest, which are conceptually similar to the correct measurement of potential output and the output gap. For 
example, an important determinant of the natural rate of interest is the trend growth rate of potential GDP, and mismeasurement of the trend growth rate is likely to affect estimates of the output gap as well as the natural rate. Estimates of the natural rate are subject to a great deal of uncertainty (Orphanides and Williams, 2002; Laubach and Williams, 2003). As seen in table 1, the three measures of the natural rate differ by as much as $1-1 / 2$ percentage point, an atypically large deviation in estimates compared to the period before the Great Recession. Uncertainty about the current value of the natural rate of interest (at least the lower-frequency concepts discussed in the previous paragraph) in turn creates uncertainty about the appropriate level of the short-term interest rate to achieve a certain stance of monetary policy.

What are the implications for the design of monetary policy strategies? As emphasized by Orphanides and Williams $(2002,2007)$ and Hamilton et al. (2015), in the context of simple policy rules like the Taylor rule (equation 2) above, strategies that do not rely as much on the estimates of the natural rate tend to be more robust to this type of uncertainty. One possible way to achieve this type of robustness is a very strong response to deviations of inflation from its objective - in the example above, a large value of $\alpha$. A strong response to inflation "gaps" effectively reduces the influence of the rule's intercept on the setting of the policy rate. Alternatively, Orphanides and Williams (2002) show that, in the case in which policymakers are uncertain about both potential output and the natural rate of interest, simple rules in which the first difference of the policy rate is a function of the deviation of inflation from its objective and the first difference of the output gap perform well.

Finally, what are the implications for monetary policy of the apparent decline of the natural rate of interest since the onset of the financial crisis? If sustained, real short-term interest rates will be lower on average in the future than was typical in the postwar period. A lower 
average real interest rate in turn implies that episodes of monetary policy being constrained at the effective zero lower bound are likely to be more frequent and longer (Reifschneider and Williams 2000). While the use of large-scale asset purchases appears to have been a powerful policy tool when short-term rates were constrained by the zero lower bound following the financial crisis (see for example Engen et al. 2015), it is unclear whether a permanent expansion of the central bank's balance sheet would permanently reduce longer-term interest rates and thereby increase the natural rate of interest.

Another potential response to a permanently lower natural rate, advocated by Blanchard et al. (2010) and Ball (2014), is to mitigate the zero lower bound by raising the central bank's inflation objective. On the one hand, the experience since 2008 suggests that the zero lower bound has been more challenging for monetary policy than previously anticipated, an important consideration for the design of future monetary policy frameworks. On the other, given our limited knowledge of the way in which inflation expectations are being formed, an increase in the inflation objective might prove either ineffective, or lead to a loss of credibility that makes inflation expectations less well anchored, with adverse consequences for monetary policy’s ability to stabilize the economy. Moreover, forward guidance and large-scale asset purchases have proven to be effective partial antidotes to the zero lower bound (Williams 2014). In addition, central banks could aim to reduce nominal interest rates below zero, as has been done to a limited extent in several European jurisdictions. Even though a number of institutional hurdles may make it difficult to reduce nominal interest rates to levels that might be called for in response to a major recession, negative short-term interest rates in combination with forward guidance and asset purchases would provide central banks with a potent set of tools to respond to undesirably low inflation and economic weakness. Of course, it would be desirable to search for 
policies that sustainably raise the level of the natural rate, but these are outside the scope of monetary policy. 


\section{References}

Andrés, Javier, J. David López-Salido and Edward Nelson. 2009. "Money and the natural rate of interest: Structural estimates for the United States and the euro area," Journal of Economic Dynamics and Control, 33, 758-776.

Ball, Laurence. 2014. "The Case for a Long-Run Inflation Target of Four Percent," IMF Working Paper 14/92, June 2014.

Blanchard, Olivier, Giovanni Dell'Ariccia, and Paolo Mauro. 2010. "Rethinking Macroeconomic Policy," IMF Staff Position Note SPN/10/03.

Bomfim, Antulio. 1997. "The Equilibrium Fed Funds Rate and the Indicator Properties of TermStructure Spreads.” Economic Inquiry 35(4), 830-846.

Clark, Todd, and Sharon Kozicki. 2005. "Estimating Equilibrium Interest Rates in Real Time." The North American Journal of Economics and Finance, 16(3), 395-413.

Congressional Budget Office. 2014. “The 2014 Long-Term Budget Outlook.” July 2014.

Council of Economic Advisers. 2015. “Long-Term Interest Rates: A Survey,” July 2015. https://www.whitehouse.gov/sites/default/files/docs/interest_rate_report_final.pdf

Cúrdia, Vasco, Andrea Ferrero, Ging Cee Ng, and Andrea Tambalotti. 2015. "Has U.S. Monetary Policy Tracked the Efficient Interest Rate?' Journal of Monetary Economics, 70, 7283.

Cúrdia, Vasco. 2015. "Why So Slow? A Gradual Return for Interest Rates," Federal Reserve Bank of San Francisco Economic Letter, 2015-32, October 13, 2015.

Dupor, William. 2015. "Liftoff and the Natural Rate of Interest," Federal Reserve Bank of St. Louis Economic Synopses, 2015, No. 12. https://research.stlouisfed.org/publications/economicsynopses/2015/06/05/liftoff-and-the-natural-rate-of-interest/

Engen, Eric, Thomas Laubach, and David Reifschneider. 2015. "The Macroeconomic Effects of the Federal Reserve's Unconventional Monetary Policies," Finance and Economics Discussion Series Divisions of Research \& Statistics and Monetary Affairs Federal Reserve Board, Washington, D.C. 2015-005.

Fleischman, Charles A., and John M. Roberts. 2011. "From Many Series, One Cycle: Improved Estimates of the Business Cycle from a Multivariate Unobserved Components Model," Finance and Economics Discussion Series Divisions of Research \& Statistics and Monetary Affairs Federal Reserve Board, Washington, D.C. 2011-46. Data available at: http://www.federalreserve.gov/econresdata/frbus/files/state_space_package.zip 
Goldby, Mike, Lien Laureys and Kate Reinold. 2015. “An estimate of the UK's natural rate of interest," Bank Underground (Bank of England blog), August 11, 2015.

http://bankunderground.co.uk/2015/08/11/an-estimate-of-the-uks-natural-rate-of-interest/

Hamilton, James D., Ethan S. Harris, Jan Hatzius, and Kenneth D. West. 2015. "The Equilibrium Real Funds Rate: Past, Present, and Future," presented at the US Monetary Policy Forum, New York, February 27, 2015.

International Monetary Fund. 2014. World Economic Outlook: April 2014.

Johannsen, Benjamin K., and Elmar Mertens. 2015. "The Shadow Rate of Interest, Macroeconomic Trends, and Time-Varying Uncertainty," Federal Reserve Board, manuscript, June 2015.

Jordà, Oscar, Moritz Schularick, and Alan M. Taylor. 2012. "When Credit Bites Back: Leverage, Business Cycles, and Crises," Federal Reserve Bank of San Francisco Working Paper, 2011-27, October 2012.

Kiley, Michael T. 2015. "What Can the Data Tell Us About the Equilibrium Real Interest Rate?" Finance and Economics Discussion Series 2015-077. Washington: Board of Governors of the Federal Reserve System, August 2015.

Kim, Don H., and Jonathan H. Wright. 2005. "An Arbitrage-Free Three-Factor Term Structure Model and the Recent Behavior of Long-Term Yields and Distant-Horizon Forward Rates," Finance and Economics Discussion Series, 2005-33, Divisions of Research \& Statistics and Monetary Affairs Federal Reserve Board, Washington, D.C.

Laubach, Thomas. 2009. "New Evidence on the Interest Rate Effects of Budget Deficits and Debt." Journal of the European Economic Association, 7(4), 858-885.

Laubach, Thomas, and John C. Williams. 2003. "Measuring the Natural Rate of Interest," Review of Economics and Statistics, 85(4), November, 1063-1070.

Lubik, Thomas A., and Christian Matthes. 2015. "Calculating the Natural Rate of Interest: A Comparison of Two Alternative Approaches," Federal Reserve Bank of Richmond Economic Brief, October 2015, EB15-10.

https://www.richmondfed.org/media/richmondfedorg/publications/research/economic_brief/2015 /pdf/eb_15-10.pdf

Neiss, Katherine S., and Edward Nelson. 2003. "The real interest-rate gap as an inflation indicator," Macroeconomic Dynamics, 7, 239-262.

Orphanides, Athanasios, and John C. Williams. 2002. "Robust Monetary Policy Rules with Unknown Natural Rates," Brookings Papers on Economic Activity, Vol. 2, 63-145. 
Orphanides, Athanasios, and John C. Williams. 2007. "Robust Monetary Policy with Imperfect Knowledge," Journal of Monetary Economics, August 2007, 1406-1435.

Pescatori, Andrea, and Jarkko Turunen. 2015. "Lower for Longer: Neutral Rates in the United States," IMF Working paper 15/135, June 2015.

Reifschneider, David, and John C. Williams. 2000. "Three Lessons for Monetary Policy in a Low Inflation Era," Journal of Money, Credit and Banking, 32(4), November, 936-966.

Schularick, Moritz, and Alan M. Taylor. 2012. "Credit Booms Gone Bust: Monetary Policy, Leverage Cycles, and Financial Crises, 1870-2008." American Economic Review, 102(2): 102961.

Stock, James H., and Mark W. Watson. 2007. "Why has US Inflation Become Harder to Forecast," Journal of Money, Credit and Banking, 39, 3-33.

Summers, Lawrence H. 2014. "U.S. Economic Prospects: Secular Stagnation, Hysteresis, and the Zero Lower Bound," Business Economics, 49(2), 65-73.

Wicksell, Knut. 1936. Interest and Prices (tr. of 1898 edition by R.F. Kahn). London: Macmillan.

Williams, John C. 2003. "The Natural Rate of Interest," Federal Reserve Bank of San Francisco Economic Letter, 2003-32, October 31, 2003.

Williams, John C. 2014. "Monetary Policy at the Zero Lower Bound: Putting Theory into Practice," The Hutchins Center on Fiscal \& Monetary Policy, The Brookings Institution, January 16.

Williams, John C. 2015. "The Decline in the Natural Rate of Interest," Business Economics, 50(2), 57-60, April.

Williams, John H. 1931. “The Monetary Doctrines of J. M. Keynes.” Quarterly Journal of Economics 45(4), 547-87. 
Figure 1: Determination of the natural rate of interest

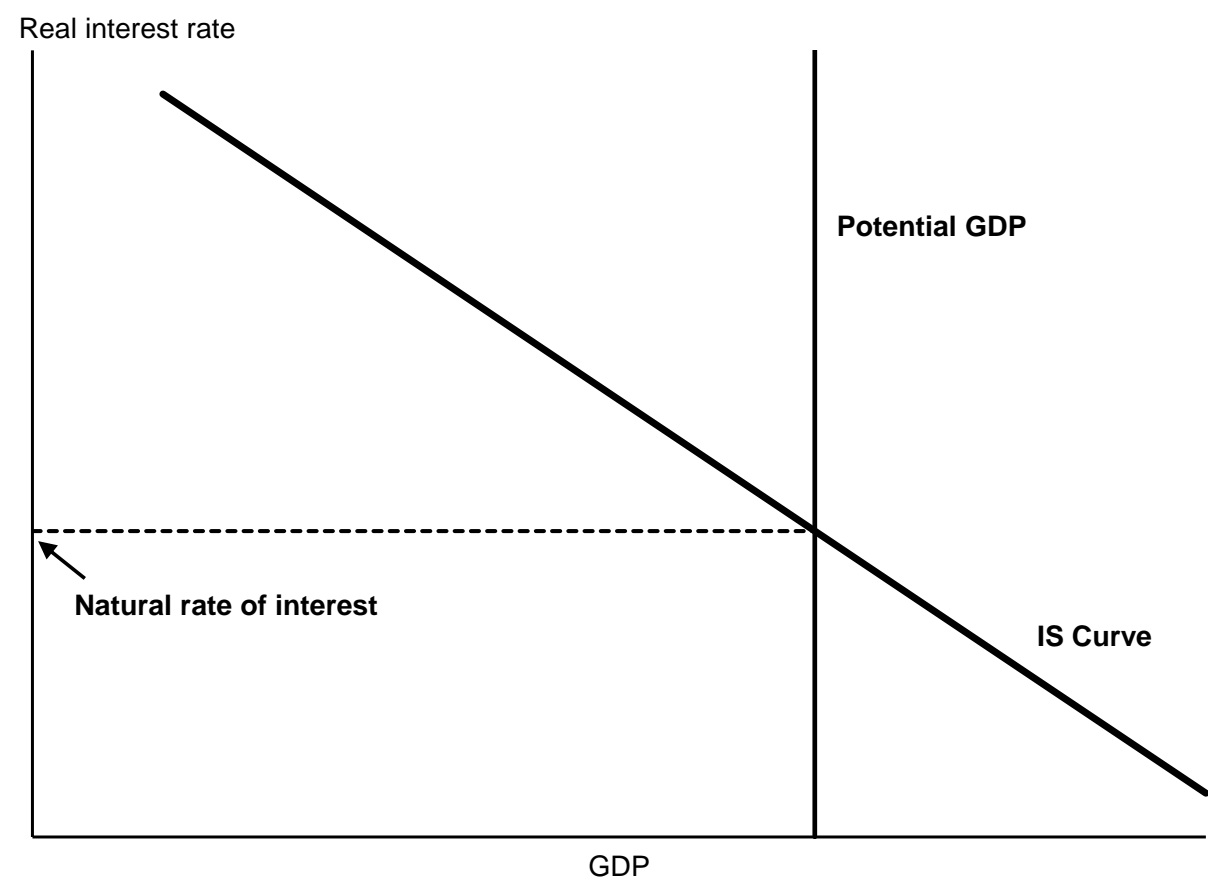

Figure 2: 10-year averages of ex post real short-term interest rates

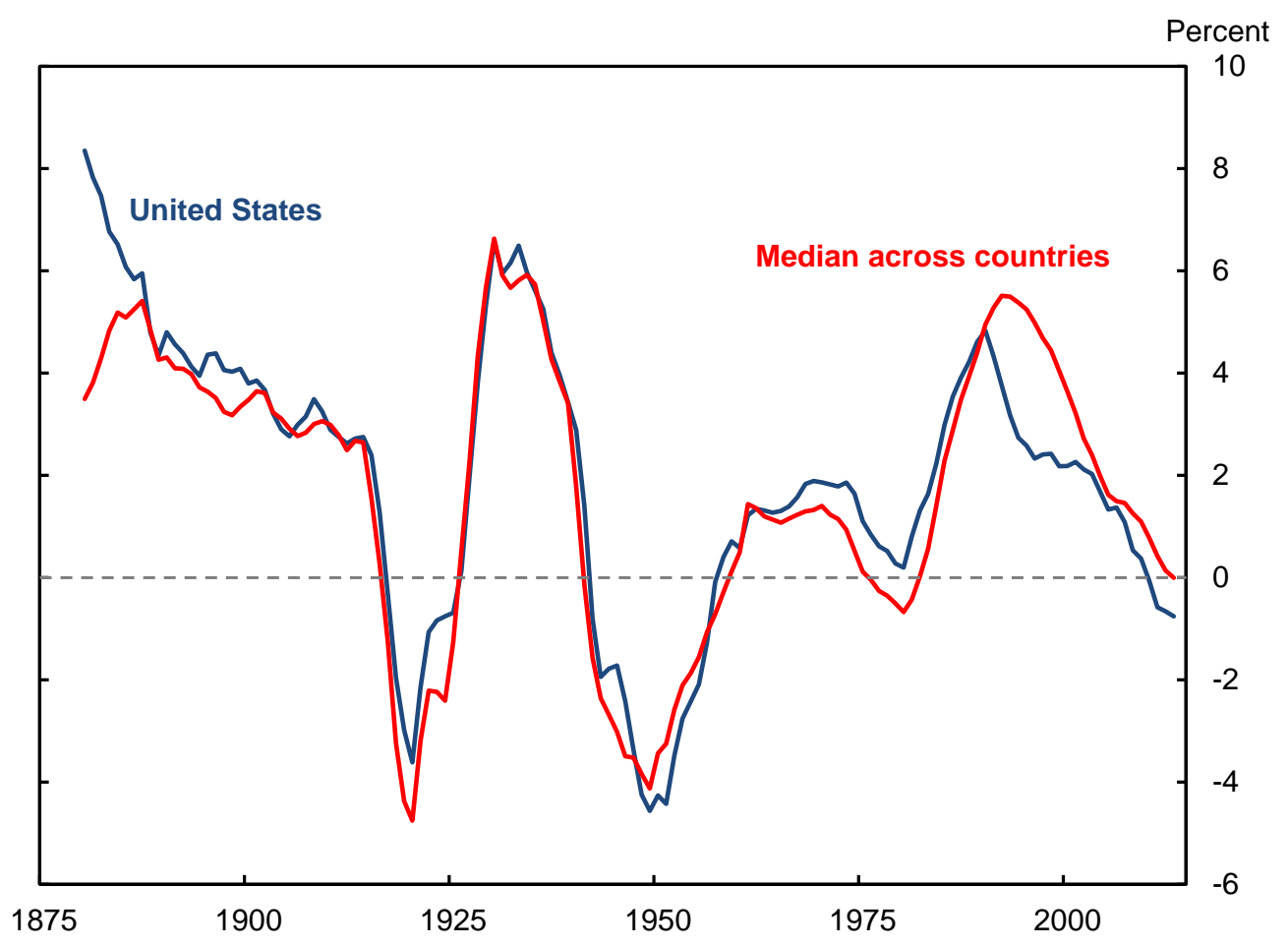


Figure 3: Univariate measures of trend real interest rates

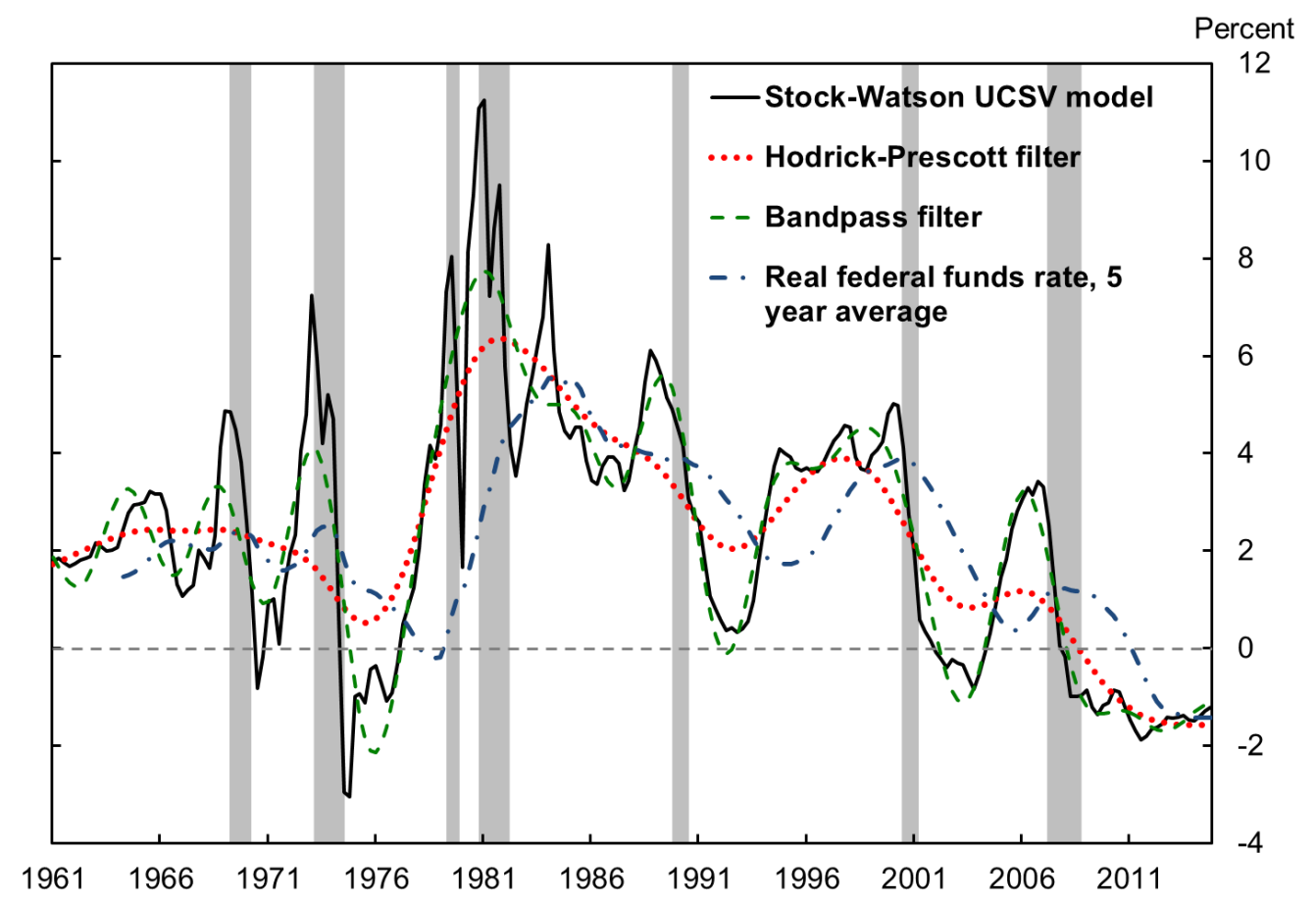

Note: Gray bands denote NBER recessions.

Figure 4: Measures of trend real interest rates from Treasury forward rates

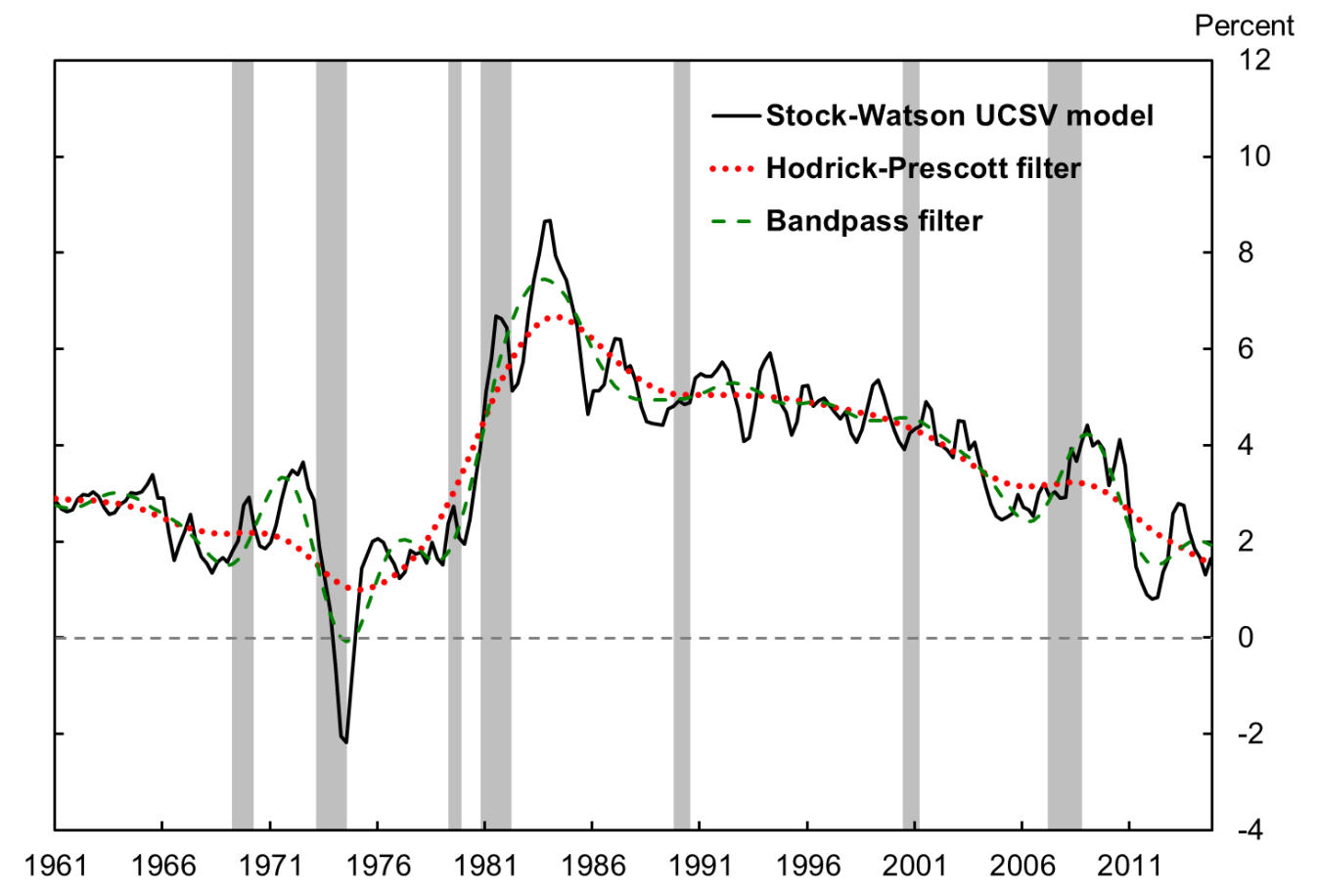


Figure 5: Laubach-Williams model estimates of the natural rate of interest

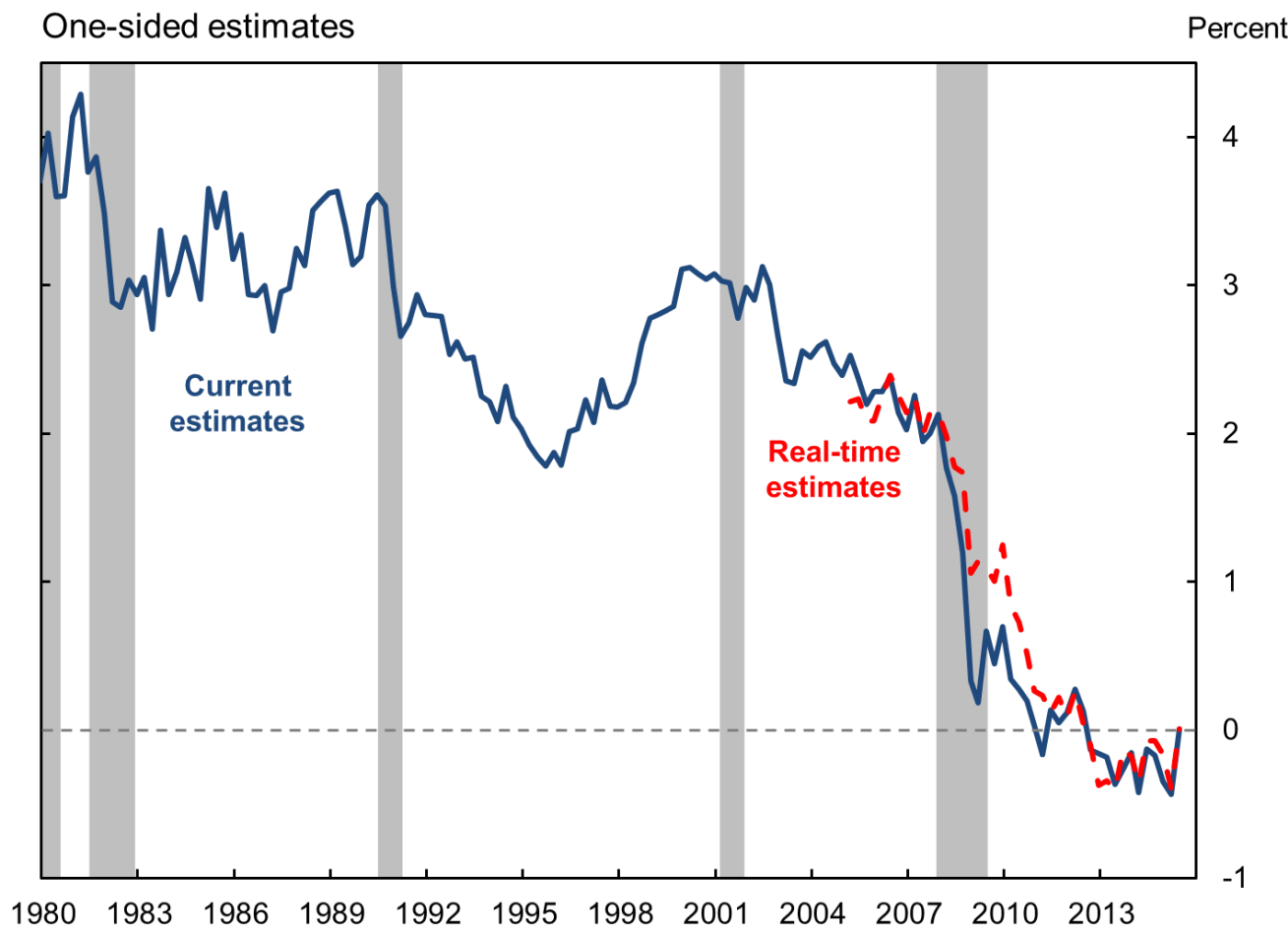

Figure 6: LW model estimates of the trend growth rate of potential output

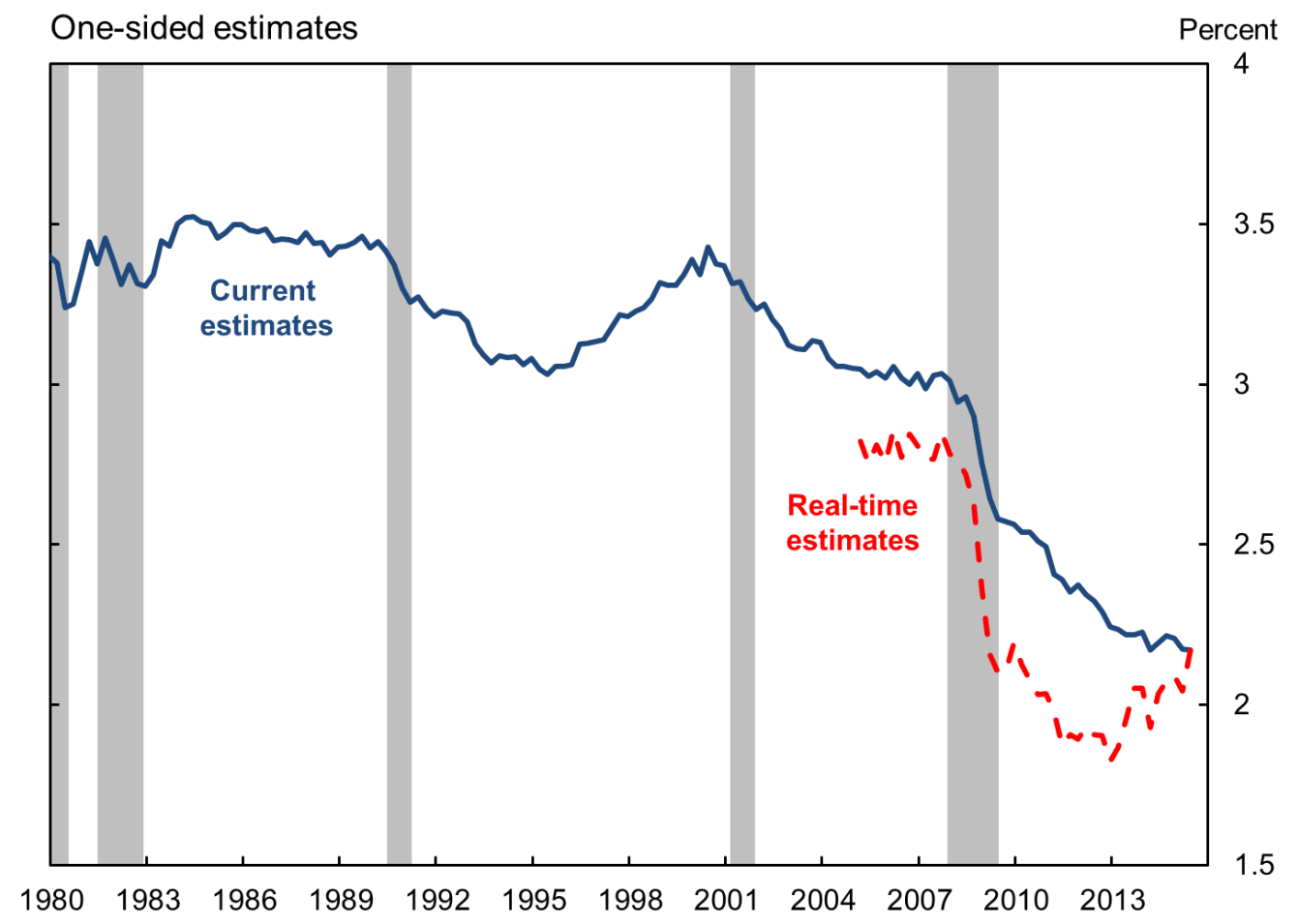


Figure 7: LW estimates of the natural rate of interest under alternative output measures

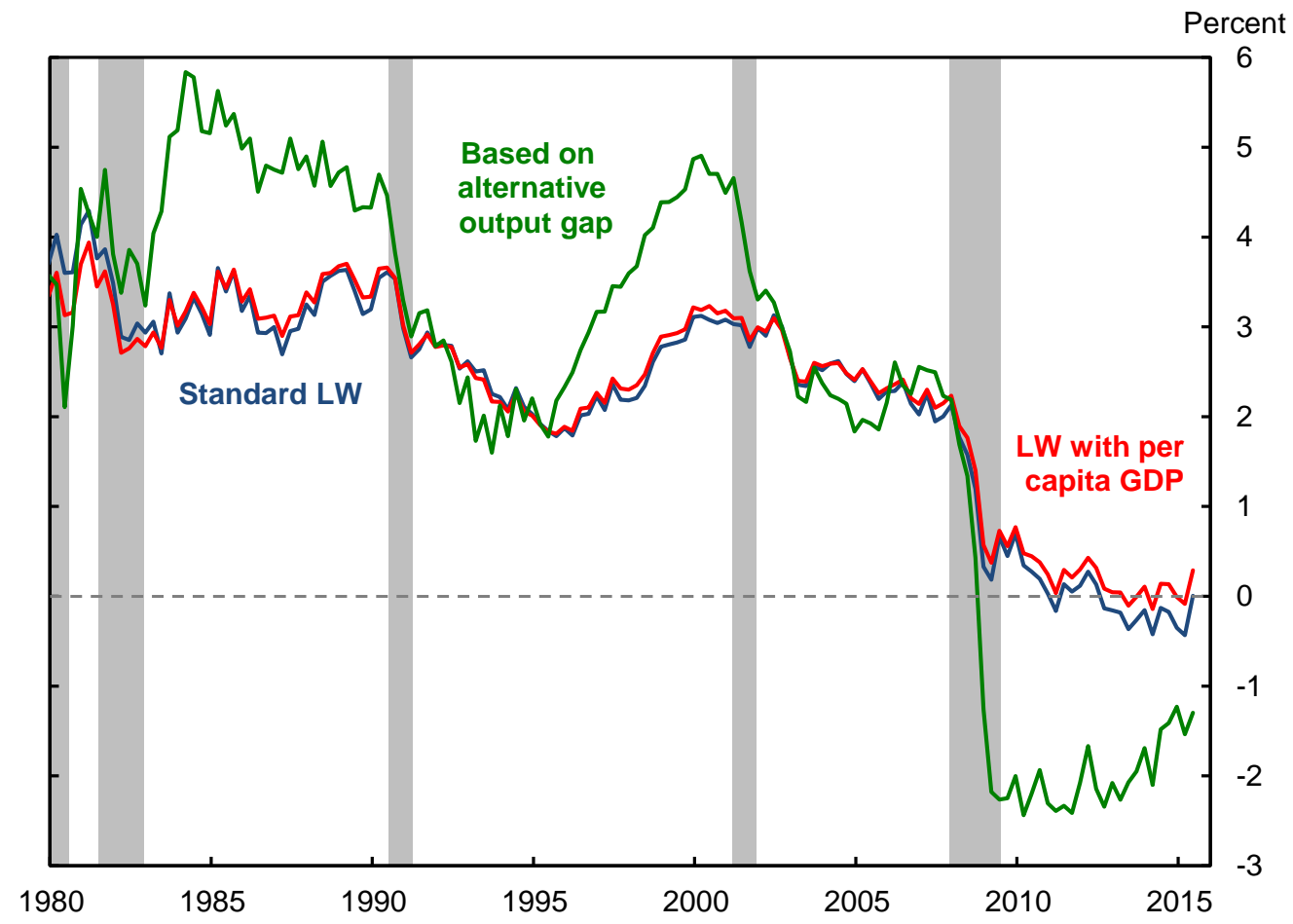

Figure 8: Alternative estimates of the output gap

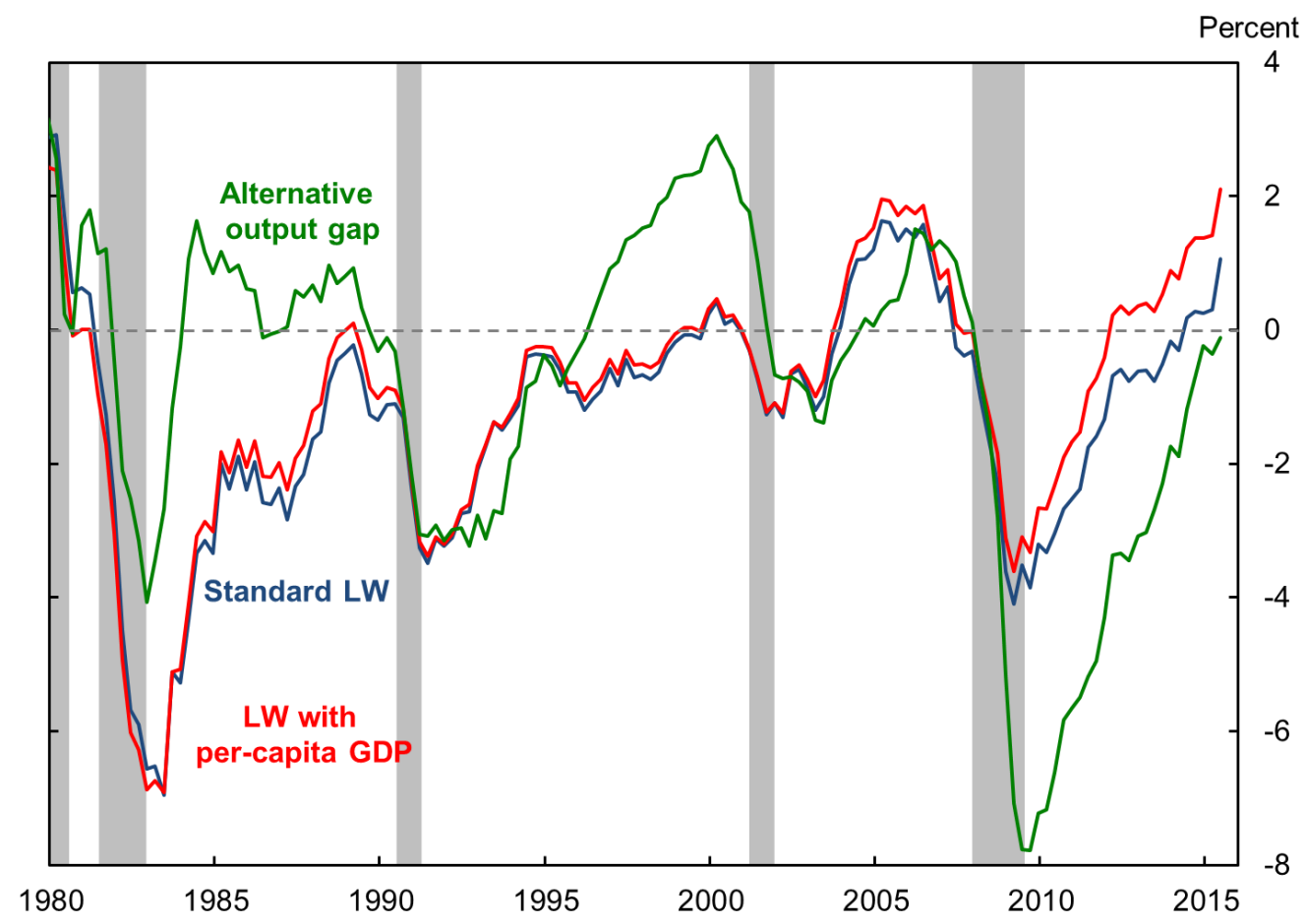


Figure 9: Interest rates following financial crises

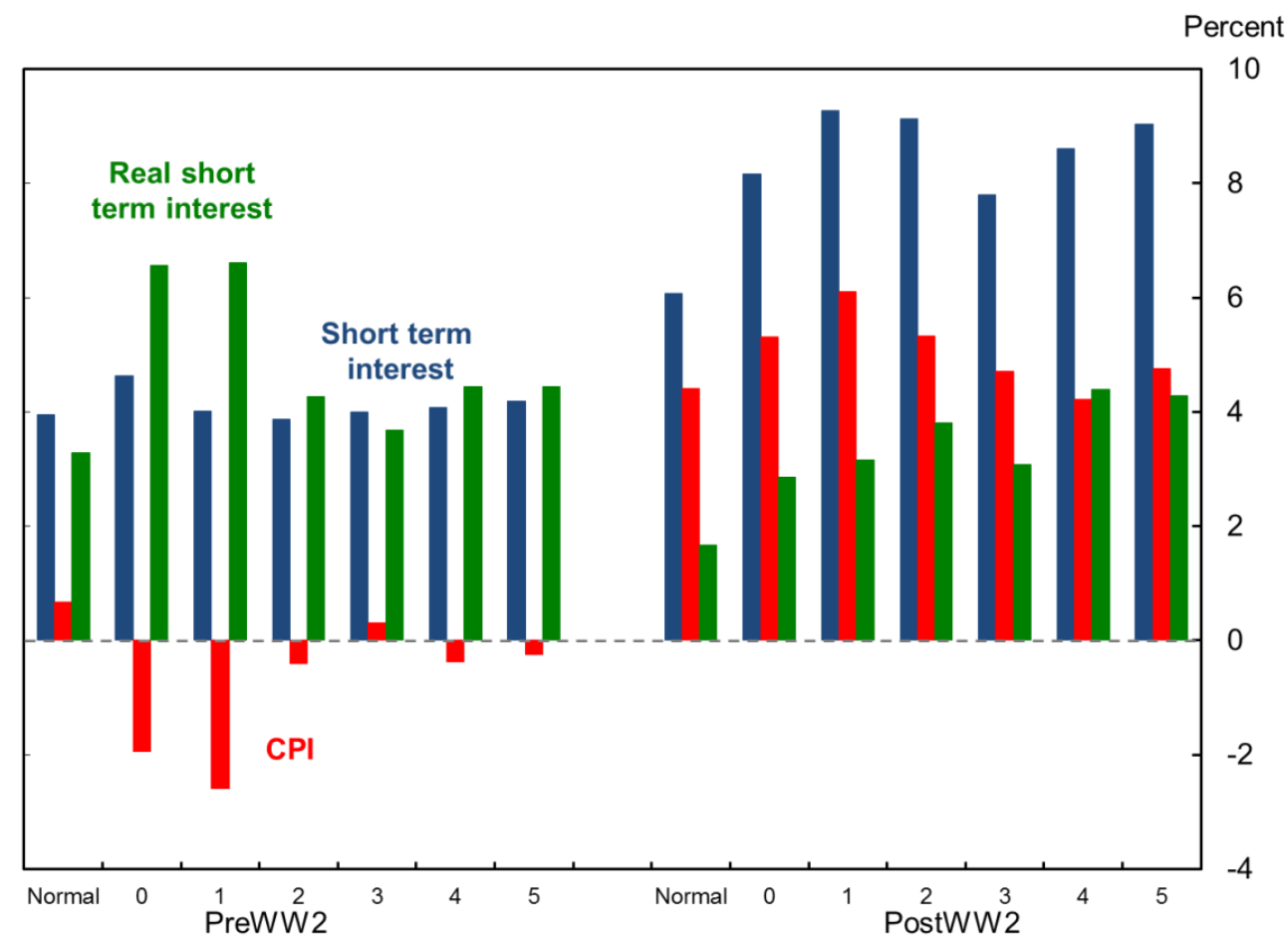

Figure 10: DSGE model forecasts of the natural rate of interest

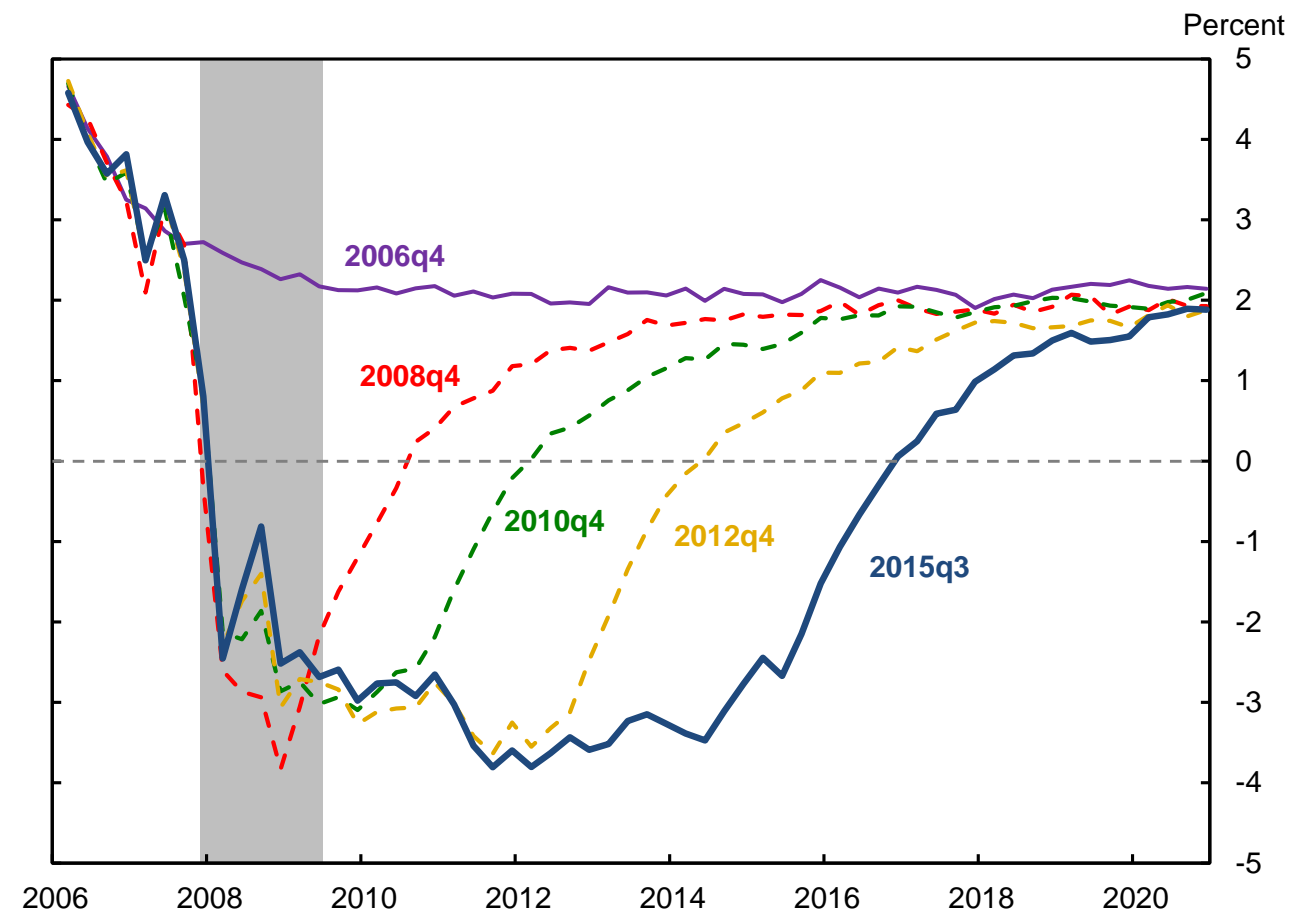


Figure 11: Alternative estimates of the natural rate of interest

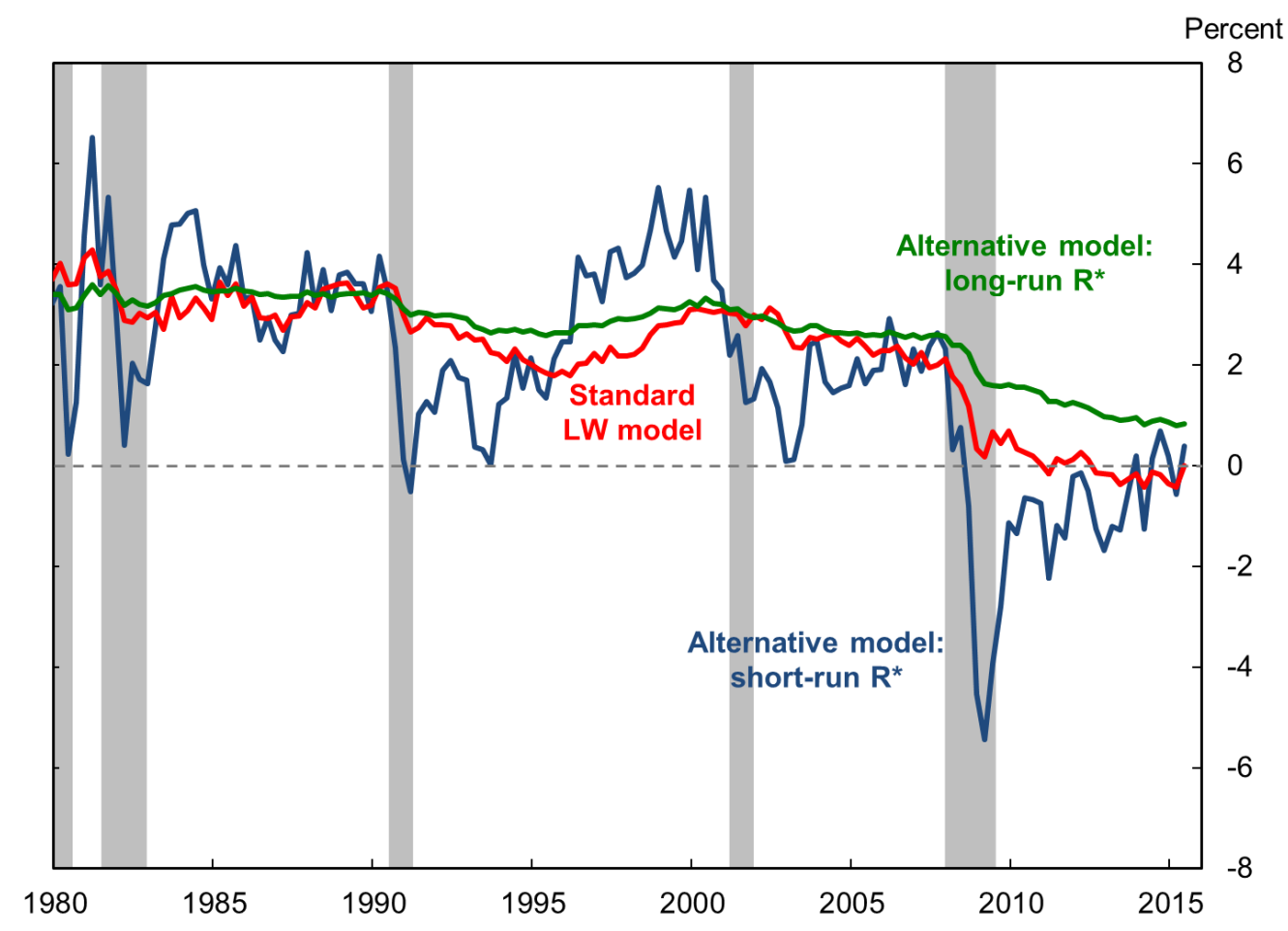


Table 1: Alternative measures of longer-run real short-term interest rates

\begin{tabular}{|l|r|r|r|r|r|}
\hline & \multicolumn{4}{|c|}{ Estimates } & \multicolumn{2}{|c|}{ Changes in estimates } \\
\hline & 1990 & 2007 & $2015 \mathrm{H} 1$ & $1990-2007$ & $2007-15 \mathrm{H} 1$ \\
\hline Blue Chip survey & 3.1 & 2.4 & 1.2 & -0.7 & -1.2 \\
\hline TIPS yields (5-10 years ahead) & $\mathrm{n} / \mathrm{a}$ & 2.5 & 0.9 & $\mathrm{n} / \mathrm{a}$ & -1.6 \\
\hline Laubach-Williams & 3.4 & 2.1 & -0.2 & -1.3 & -2.3 \\
\hline contribution from trend growth & & & & -0.4 & -1.1 \\
\hline contribution from other factors & & & & -0.9 & -1.2 \\
\hline
\end{tabular}

*Numbers may not sum due to rounding.

Table 2: Real interest rates following crises

\begin{tabular}{lccccc}
\hline \hline & Year 1 & Year 2 & Year 3 & Year 4 & Year 5 \\
\hline Normal recession indicator & 0.195 & 0.146 & 0.0721 & -0.425 & -0.0138 \\
& $(0.575)$ & $(0.597)$ & $(0.540)$ & $(0.723)$ & $(0.721)$ \\
& & & & & \\
Financial recession indicator & -0.192 & 0.375 & -0.138 & -1.670 & -0.216 \\
& $(1.000)$ & $(1.038)$ & $(0.939)$ & $(1.257)$ & $(1.252)$ \\
& & & & & \\
Excess credit x normal recession & -0.0420 & -0.113 & 0.139 & 0.0990 & -0.0506 \\
& $(0.283)$ & $(0.293)$ & $(0.265)$ & $(0.355)$ & $(0.354)$ \\
& & & & & \\
Excess credit x financial recession & 0.591 & $0.736+$ & $0.682+$ & 0.810 & 0.363 \\
& $(0.394)$ & $(0.409)$ & $(0.370)$ & $(0.495)$ & $(0.494)$ \\
\hline Obs, Norm & 97.00 & 97.00 & 97.00 & 97.00 & 97.00 \\
Obs, Fin & 32.00 & 32.00 & 32.00 & 32.00 & 32.00 \\
F-test Equality of coefficients, Normal=Financial & 0.74 & 0.85 & 0.85 & 0.39 & 0.89 \\
F-test Equality of coefficients, interaction terms & 0.19 & 0.09 & 0.24 & 0.25 & 0.50 \\
Observations & 129 & 129 & 129 & 129 & 129 \\
\hline \hline
\end{tabular}

Standard errors in parentheses

LM test: All excess credit coefficients equal zero: $F(10,625)=3.995 ; p=0.000$

Dependent variable: ex post real short-term interest rate

$+p<0.1$ 